\title{
Kajian Tentang Efek Pemberian Blondo Dalam Ransum Terhadap Performans Ayam Broiler
}

\author{
Husmaini, M.H. Abbas dan L. Y. Putri,
}

Fakultas Peternakan Universitas Andalas Padang.

\begin{abstract}
An experiment was conducted to studi the effect of the blondo in diet to the performance chicken. Five diets were formulated with different level blondo in diet i.e: (A) $0 \%$, (B) 3 $\%$, (C) $6 \%$, (D) $9 \%$ and (E) $12 \%$. The diets were offered for 6 weeks to 80 broiler chickens 3 old days. Variable measured inchaded : feed consumption, body weight gain, $F C R$, carcass and percentage of abdominal fat. The data were statically analyzed for variance analysis in completely randomized design. The results indicated that $12 \%$ blondo in diet gave significant effect to improved performance of broller chickens.
\end{abstract}

Key Words : Blondo, fced consumption, body weight gain, FCR, carcass, abdominal fat

\section{Pendahuluan}

Semakin meningkatnya taraf kehidupan dan kesadaran masyarakat akan kebutuhan gizi terutama yang berasal dari hewani, maka permintaan terhadap ternak juga semakin meningkat. Namun peningkatan permintaan belum dapat diimbangi olch peningkatan produksi ternak. Keadaan ini merupakan peluang untuk pengembangan ternak ayam broiler sebagai sumber protein hewani.

Usaha peternakan ayam broiler merupakan usaha yang prospektif karena dengan pertumbuhannya yang sangat cepat dapat menghasilkan daging dalam waktu yang relatif singkat, (kurang dari 8 minggu) dan harga terjangkau. Dalam beternak ayam broiler pengadaan bahan pakan untuk penyusun ransum merupakan hal yang utama, karena ayam broiler menggunakan ransum untuk memenuhi kebutuhan hidupnya selama 24 jam dan menghasilkan pertumbuhan yang optimal

Blondo merupakan limbah industri pertanian sisa pembuatan minyak kelapa murni yang biasa disebut virgin coconut oil (VCO). Minyak kelapa murni (VCO) terbuat dari santan kelapa tua yang masih segar, dimana proses pengolahannya tidak menggunakan bahan kimia dan pemanasan tinggi. VCO memiliki kadar air dan kadar asam lemak bebas yang rendah, warna bening dan berbau harum. Daya simpannya pun menjadi lebih lama, bisa lebih dari dua belas bulan. VCO tidak mengandung kolesterol dan mengandung asam laurat yang dapat diubah menjadi monolaurin yang bersifat anti virus, antibakteri, dan antiprotozoa yang mampu mengatasi infeksi virus, bakteri, dan protozoa. (Syah, 2005). Banyaknya manfaat VCO ini diharapkan masih terkandung di dalam blondo yang merupakan sisa dari pembuatan VCO sehingga dapat dipergunakan sebagai makanan ternak

Perkembangan bisnis minyak kelapa pada saat sckarang ini melaju pesat. Ini juga didukung oleh wilayah Indonesia yang beriklim tropis, dimana total area perkebunan kelapa di Indonesia mencapai 3,712 juta 
Hektar $(31,4 \%$ dari luas perkebunan seluruh Indonesia). Khusus di Sumatera Barat luas perkebunan kelapa mencapai 94,199 Ha dengan produksi 8,6 ton/Ha/th (Biro Pusat Statistik Sumbar, 2004). Kondisi ini akan turut mendukung dihasilkannya blondo. Dalam pengolahan minyak kelapa murni, dari 40 butir buah kelapa segar akan dihasilkan 3 liter VCO dan $2 \mathrm{~kg}$ blondo. Dari data diatas, berdasarkan perhitungan akan diperoleh blondo sekitar $24.303,342$ ton/th.

Blondo berpotensi untuk dimanfaatkan sebagai bahan pakan ternak unggas karena mempunyai kandungan protein dan energi cukup tinggi. Berdasarkan hasil analisis proksimat diketahui bahwa blondo basah mengandung $26,6 \%$ protein kasar; $37,50 \%$ lemak kasar; 1,29\% serat kasar; $0,31 \% \mathrm{P}$ dan $1,39 \% \mathrm{Ca}$; 58 dan $4548 \mathrm{kkal} / \mathrm{kg}$ ME; serta asam lemak tak jenuh berantai sedang diantaranya $14,321 \%$ asam lemak oleat (omega-9); 0,166\% asam lemak linoleat (omega-6);0,052 \% asam lemak linolenat (omega-3) (Hasil Analisis Laboratorium $1 \mathrm{mu}$ dan Teknologi Pakan Fakultas Peternakan Institut Pertanian Bogor, 2005). Dari hasil analisis tersebut, blondo berpotensi dijadikan sebagai sumber protein sekaligus sebagai sumber energi, sehingga dapat mengurangi pemakaian bungkil kedele sebagai sumber protein nabati dan pemakaian jagung sebagai sumber energi dalam ransum. Di samping itu, blondo mengandung asam lemak tak jenuh berantai sedang, yaitu asam oleat, linoleat, dan linolenat. Asam lemak tak jenuh yang terdapat dalam blondo merupakan asam lemak esensial, harus tersedia dalam ransum karena ayam tidak bisa mensintesanya. Asam lemak ini dapat membantu dalam penyerapan vitamin-vitamin yang larut dalam lemak, sehingga meningkatkan penyerapan nutrisi dari bahan makanan.

Kendala pemanfaatan blondo sebagai bahan pakan ternak unggas adalah kandungan lemaknya yang cukup tinggi, sehingga taraf pemberian blondo terbatas disesuaikan dengan batas toleransi lemak dalam ransum unggas. Menurut North (1994) jumlah lemak yang dapat diberikan pada ayam broiler sampai taraf $8 \%$ jika lebih akan memberikan pengaruh yang buruk pada pertumbuhan ayam broiler.

Penelitian ini bertujuan untuk mempelajari pengaruh pemberian blondo terhadap konsumsi ransum, pertambahan bobot badan, konversi ransum, rataan bobot karkas, persentase bobot karkas dan lemak abdomen.

\section{Materi Dan Metoda}

Percobaan ini menggunakan 80 ekor ayam broiler strain Cobb umur 3 hari yang ditempatkan dalam 20 unit kandang box berukuran $75 \times 60 \times 60$ $\mathrm{cm}$, dilengkapi dengan tempat makan dan minum serta lampu listrik 60 Watt sebagai sumber pemanas.

Runsun Itrdiri duri buluan makanan jagung, dedak, bungkil kedelai, bungkil kelapa, tepung ikan, tepung tulang, dan blondo. Blondo yang digunakan diperoleh dari $\mathrm{CV}$. Barokah Pariaman yang dikeringkan dengan cara menyangrai kemudian dijemur. Kandungan zat-zat makanan dan energi metabolisme bahan penyusun ransum disajikan pada Tabel 1, sedangkan komposisi bahan penyusun ransum perlakuan dan kandungan zat-zat makanan serta energi matabolisme ransum perlakuan, masing-masing disajikan pada Tabel 2 dan Tabel 3. 
Tabel 1. Kandungan Zat - Zat Makanan (\%) dan Energi Metabolisme (Kkal/kg) Bahan Penyusun Ransum (As feed basis)

\begin{tabular}{|c|c|c|c|c|c|c|}
\hline $\begin{array}{l}\text { Bahan } \\
\text { Pakan }\end{array}$ & PK & Lmk & SK & $\mathrm{Ca}^{b}$ & $\mathbf{P}^{b}$ & $\mathrm{ME}^{\mathrm{b}}$ \\
\hline J.Kuning ${ }^{2}$ & 8,60 & 3,90 & 2,00 & 0,02 & 0,10 & 3370 \\
\hline D.Halus ${ }^{2}$ & 14,00 & 12,00 & 12,00 & 0,12 & 0,21 & 2565 \\
\hline T.Ikan ${ }^{a}$ & 44,00 & 2,00 & 1,00 & 4,00 & 2,60 & 2630 \\
\hline B.Kelapa ${ }^{a}$ & 24,00 & 12,00 & 15,00 & 0,20 & 0,20 & 1540 \\
\hline B.Kedele" & 45,00 & 0,90 & 6,00 & 0,32 & 0,29 & 2240 \\
\hline Blondo ${ }^{*}$ & 26,6 & 37,50 & 1,29 & 1,39 & 0,31 & $4548^{\circ}$ \\
\hline T.Tulang & 0,00 & 0,00 & 0,00 & 24,00 & 12,00 & 0,00 \\
\hline Keterangan : & $\begin{array}{l}\text { a. Hasil Analisi } \\
\text { Universitas } \\
\text { b. Tabel Scott } \\
\text { * Hasil Analisi } \\
\text { Institut Perts } \\
\text { ** Dihitung be } \\
\text { ME - (EProts }\end{array}$ & $\begin{array}{l}\text { boratoriu } \\
\text { las (2006 } \\
\text { (1982) } \\
\text { thoratoriu } \\
\text { Bogor ( } \\
\text { tarkan NF } \\
(4.4)+(2\end{array}$ & $\begin{array}{l}\text { Imu dan } \\
5) \\
(1984) \text {, y } \\
\text { mak x 8. } \\
0\end{array}$ & $\begin{array}{l}\text { nologi } \\
\text { (EBET }\end{array}$ & Fakult & nakan \\
\hline
\end{tabular}

Tabel 2. Komposisi Bahan Makanan dan Kandungan Gizi (\%) serta Energi Metabolisme Ransum Percobaan

\begin{tabular}{lrrrrr}
\hline & \multicolumn{5}{c}{ Periakuan } \\
\cline { 2 - 6 } & $\mathrm{A}$ & $\mathrm{B}$ & $\mathrm{C}$ & $\mathrm{D}$ & $\mathrm{E}$ \\
\hline Bahan Makanan & 58,50 & 53,88 & 49,25 & 44,62 & 40,00 \\
\hline Jagung Kuning & 2,50 & 4,88 & 7,25 & 9,62 & 12,00 \\
Dedak Halus & 14,00 & 14,00 & 14,00 & 14,00 & 14.00 \\
Tepung Ikan & 7,50 & 7,50 & 7,50 & 7,50 & 7,50 \\
Bungkil Kelapa & 17,00 & 16,25 & 15,50 & 14,75 & 14,00 \\
Bungkil Kedele & 0,00 & 3,00 & 6,00 & 9,00 & 12,00 \\
Blondo & 0,50 & 0,50 & 0,50 & 0,50 & 0,50 \\
Tepung Tulang & 22,17 & 22,13 & 22,08 & 22,04 & 21,99 \\
\hline Kandungan Gizi (\%) serta Energi Metabolisme & & & \\
\hline Protein & 2,97 & 4,05 & 5,14 & 6,22 & 7,80 \\
Lemak & 3,76 & 3,91 & 4,07 & 4,22 & 4,11 \\
SK & 0,76 & 0,81 & 0,85 & 0,89 & 1,4 \\
Ca & 0,55 & 0,56 & 0,57 & 0,57 & 0,94 \\
P & 002,6 & 3012,34 & 3022,08 & 3031,82 & 3041,56 \\
ME & & & & &
\end{tabular}


Penelitian ini merupakan eksperimen yang menggunakan Rancangan Acak Lengkap (RAL) dengan 5 perlakuan dan 4 ulangan. Setiap unit percobaan terdiri dari 4 ekor ayam broiler. Perlakuan yang diberikan adalah tingkat pemberian blondo dalam ransum yaitu :

Perlakuan $\mathrm{A}=$ pemberian $0 \%$ blondo Perlakuan $\mathrm{B}=$ pemberian $3 \%$ blondo Perlakuan $\mathrm{C}=$ pemberian $6 \%$ blondo Perlakuan $\mathrm{D}=$ pemberian $9 \%$ blondo Perlakuan $\mathrm{E}=$ pemberian $12 \%$ blondo Model matematis dari rancangan ini menurut Steel dan Torrie (1995) adalah sebagai berikut :

$$
\mathrm{Yij}=\mu+\sigma \mathrm{i}+\Sigma \mathrm{ij}
$$

Data yang diperoleh diolah secara statistik dengan analisis ragam sesuai dengan rancangan yang digunakan sedangkan uji lanjut menggunakan DMRT menurut Steel dan Torrie (1995).

Peubah yang diamati dalam penelitian ini adalah, Konsumsi ransum, Pertambahan bobot badan, Konversi ransum, Bobot karkas,
Persentase karkas dan Lemak abdomen.

\section{Hasil Dan Pembahasan}

\section{A. Pengaruh Perlakuan Terhadap Konsumsi Ransum, Pertamba- han Bobot Badan dan Konversi Ransum.}

Rataan kosumsi ransum, pertambahan bobot badan dan konversi ransum ayam broiler untuk masing-masing perlakuan selama enam minggu penelitian disajikan pada Tabel 3. Hasil analisis ragam memperlihatkan bahwa pemberian blondo dalam ransum berpengaruh sangat nyata $(P<0,01)$ terhadap konsumsi ransum. Dari uji lanjut terlihat diketahui bahwa pemberian blondo sampai taraf $6 \%$ dalam ransum (C) belum nyata $(\mathrm{P}>0,05)$ menyebabkan perbedaan jumlah konsumsi ransum, tetapi pada taraf 9 $\%$ (D) dan $12 \%$ (E) menyebabkan jumlah konsumsi ransum sangat nyata $(\mathrm{P}<0,01)$ lebih rendah.

Tabel 3. Rataan Kosumsi Ransum, Pertambahan Bobot Badan, dan Konversi Ransum Ayam Broiler Selama Enam Minggu Penelitian

\begin{tabular}{cccccc}
\hline Perlakuan & $\begin{array}{c}\text { Konsumsi } \\
\text { Ransum } \\
\text { (gram/ekor) }\end{array}$ & $\begin{array}{c}\text { Intake } \\
\text { Lemak } \\
\text { (gram/ekor) }\end{array}$ & $\begin{array}{c}\text { Intake Asam } \\
\text { Lemak Tak } \\
\text { Jenuh } \\
\text { (gram/ekor) }\end{array}$ & $\begin{array}{c}\text { Pertambahan } \\
\text { Bobot Badan } \\
\text { (gram/ekor) }\end{array}$ & $\begin{array}{c}\text { Konversi } \\
\text { Ransum }\end{array}$ \\
\hline A $(0 \%)$ & $3178,75^{\mathrm{A}}$ & $95,37^{\mathrm{A}}$ & $0,00^{\mathrm{A}}$ & $1781,18^{\mathrm{A}}$ & $1,78^{\mathrm{A}}$ \\
$\mathrm{B}(3 \%)$ & $3165,00^{\mathrm{AB}}$ & $132,93^{\mathrm{B}}$ & $5,18^{\mathrm{B}}$ & $1846,13^{\mathrm{ab}}$ & $1,71^{\mathrm{A}}$ \\
$\mathrm{C}(6 \%)$ & $3143,75^{\mathrm{ABC}}$ & $169,60^{\mathrm{C}}$ & $10,29^{\mathrm{C}}$ & $1935,63^{\text {bc }}$ & $1,63^{\mathrm{AB}}$ \\
D $(9 \%)$ & $3118,13^{\mathrm{BC}}$ & $205,18^{\mathrm{D}}$ & $15,30^{\mathrm{D}}$ & $1968,00^{\mathrm{bc}}$ & $1,59^{\mathrm{AB}}$ \\
E $(12 \%)$ & $3100,00^{\mathrm{C}}$ & $244,80^{\mathrm{E}}$ & $20,28^{\mathrm{E}}$ & $2076,75^{\mathrm{C}}$ & $1,49^{\mathrm{B}}$ \\
SF & 11,69 & 0,56 & 0,08 & 56,64 & 0,045 \\
\hline
\end{tabular}

Ket : ${ }^{X B C}$ Superskrip berbeda menunjukkan perbedaan yang sangat nyata ( $\left.\mathrm{P}<0,01\right)$ ${ }^{a k}$ Superskrip berbeda menunjukkan perbedasan yang nyata ( $P<0,05$ ) 
Dari Table 3 terlihat bahwa dari hasil perhitungan diketahui intake lemak masing - masing perlakuan semakin tinggi dengan semakin banyak taraf pemberian blondo dalam ransum. Pemberian blondo $12 \%$ meningkatkan intake lemak 156,68\%. Menurut Wahyu (1997) penggunaan lemak dalam ransum ternak yang sedang dalam periode pertumbuhan, dapat meningkatkan efesiensi penggunaan energi yang dikonsumsi menjadi lebih bagus dibandingkan dengan ternak yang diberi ransum yang berkadar lemak rendah. Meningkatnya taraf pemberian blondo dalam ransum menyebabkan lemak ransum meningkat, sehingga lebih efisien dalam penggunaaan ransum akibat kebutuhan energi cepat tepenuhi. Pada penelitian ini sebagian lemak ransum berasal dari lemak blondo dalam bentuk asam lemak tak jenuh berantai sedang yang mudah dicerna, diserap dan diangkut ke seluruh tubuh sebagai sumber energi. Berdasarkan perhitungan dengan penambahan blondo $12 \%$ dalam ransum menyebabkan peningkatan intake asam lemak tak jenuh $20,28 \%$. Oleh sebab itu dengan meningkatnya taraf pemberian blondo dalam ransum, kebutuhan ayam broiler akan energi cepat terpenuhi dibandingkan tanpa pemberian blondo. Menurut Syukur (2004) asam linolenat (omega-9), linoleat (omega-6) dan oleat (omega9), langsung dimetabolisme didalam tubuh dan menghasilkan energi yang tinggi. Sesuai dengan pendapat Wahju (1997), ayam makan untuk memenuhi kebutuhan energinya dan berhenti makan bila kebutuhan energinya sudah terpenuhi. Pada penelitian ini konsumsi ransum ayam yang mendapat perlakuan level blondo lebih tinggi akan sedikit konsumsi ransumnya karena kebutuhan energi sudah terpenuhi.

Hal lain yang menyebabkan semakin rendahnya konsumsi ransum ayam broiler dengan penambahan blondo dalam ransum adalah dugaan bahwa di dalam blondo masih terkandung asam laurat berantai medium (MCFA) seperti yang terkandung didalam minyak kelapa murni yang mana langsung dibakar oleh tubuh sehingga lebih mudah diserap oleh tubuh dibandingkan asam lemak berantai panjang. Sibuea (2004) menyatakan bahwa asam laurat berantai medium (MCFA) jauh lebih mudah dicerna, diserap dan diangkut ke seluruh tubuh sebagai sumber energi. Dengan cara ini dapat memenuhi kebutuhan ayam broiler akan energi dengan cepat.

Dari Tabel 3 terlihat ayam yang mengkonsumsi ransum tanpa pemberian blondo mempunyai pertambahan bobot badan paling rendah yaitu 1781,19 gram (A) dan paling tinggi adalah ayam yang mendapat perlakuan dengan pemberian blondo $12 \%$ yaitu 2076,75 gram (E) atau meningkat $16,59 \%$. Hasil analisis ragam memperlihatkan bahwa pemakaian blondo pengaruh nyata $(\mathrm{P} \odot 0,05)$ terhadap pertambahan bobot badan ayam broiler. Dari uji lanjut terlihat bahwa pemakaian blondo sampai taraf $6 \%$ belum menghasilkan pertambahan bobot badan yang berbeda, tetapi pemberian blondo $9 \%$ (D) dan $12 \%$ (E) nyata $(\mathrm{P}<0,05)$ meningkatkan pertambahan bobot badan ayam.

Tingginya pertambahan bobot badan yang dihasilkan berarti penambahan blondo telah dapat memperbaiki kualitas ransum yang diberikan, dimana dengan konsumsi yang lebih sedikit ternyata pertambahan bobot badan yang 
dihasilkan lebih besar. Hal ini disebabkan karena asam lemak tak jenuh di dalam blondo yaitu asam oleat, linoleat dan linolenat, merupakan asam lemak esensial, yang tersedia dalam ransum. Anggorodi (1995) menyatakan bahwa kekurangan asam lemak esensial di dalam ransum menimbulkan penyakit defisiensi dengan gejala - gejala pertumbuhan terganggu, hati berlemak dan daya tahan tubuh menurun terhadap infeksi pernapasan. Penambahan blondo dalam ransum meningkatkan pertambahan bobot badan ayam broiler. Ini disebabkan karena penambahan blondo telah memberikan sumbangan peningkatan asam lemak esensial di dalam ransum, sehingga adanya keseimbangan asam lemak esensial di dalam ransum. Di samping itu lemak dapat meningkatkan penyerapan vitamin yang larut di dalam lemak yaitu vitamin A, D, E dan K. Menurut Anggorodi (1995) kekurangan vitamin A dapat menyebabkan pertumbuhan terganggu dan kekebalan terhadap beberapa penyakit juga menurun. Siregar dkk. (1980) menyatakan bahwa pertambahan berat badan ayam broiler sangat dipengaruhi oleh kandungan zat makanan dalam ransum yang sesuai dengan kebutuhannya.

Hal lain yang menyebabkan pertambahan bobot lebih tinggi dengan penambahan blondo yang lebih banyak dalam ransum adalah karena di dalam blondo terdapat bakteri asam laktat yaitu Lactobacillus sp. Bakteri ini berfungsi sebagai probiotik yang dapat menekan aktifitas bakteri patogen (Purwati dkk. 2006). Menurut Murni (2006) jumlah Lactobacillus sp dalam blondo mencapai $5,29 \times 10^{9} \mathrm{CPU} / \mathrm{gram}$ sehingga dapat dikategorikan sebagai probiotik. Diduga sebagian bakteri asam laktat tersebut masih terbawa dalam ransum sampai ke usus halus sehingga dapat meningkatkan penyerapan zat - zat makanan di dalam usus yang pada akhirnya akan berpengaruh akan petumbuhan ayam broiler. Namun dugaan ini perlu kajian lebih lanjut dengan mengkaji aktifitas bakteri asam laktat dalam usus halus.

Dari Tabel 3 Rataan konversi ransum setiap ekor per minggu selama penelitian terlihat konversi ransum terbaik (terendah) dicapai pada perlakuan $E$, diikuti berturut - turut D,C,B,A dimana konversi ransum menjadi lebih baik dengan pemakaian blondo dalam ransum. Hasil analisis ragam memperlihatkan bahwa blondo berpengaruh sangat nyata $(\mathrm{P}<0,01)$ terhadap konversi ransum. Dari Uji lanjut diketahui bahwa pemberian blondo sampai taraf $9 \%$ (C) tidak memberikan perbedaan yang nyata $(\mathrm{P}>0,05)$ terhadap konversi ransum, tetapi pemberian blondo sampai taraf $12 \%$ (E) sangat nyata ( $<<0,01)$ menurunkan konversi ransum ayam broiler.

Meningkatnya taraf pemberian blondo dalam ransum telah meningkatkan pertambahan bobot badan ayam broiler sedangkan konsumsi ransum semakin berkurang sehingga konversi ransum yang didapatkan semakin rendah. Sesuai pendapat Scott et al. (1982), bahwa besarnya nilai konversi ransum ditentukan oleh banyaknya konsumsi ransum dan pertambahan bobot badan yang dihasilkan. Sarwono (1994) menyatakan, bahwa konversi ransum berhubungan erat dengan pertambahan bobot badan, semakin rendah konsumsi ransum yang diikuti oleh pertambahan bobot badan yang tinggi menghasilkan konversi ransum yang baik Anggorodi (1994) menjelaskan bahwa tujuan pemberian makanan adalah untuk mendapatkan berat 
badan yang paling ekonomis selama pertumbuhan. Dalam penelitian ini didapatkan bahwa pemberian blondo sebanyak $12 \%$ telah menekan konversi ransum broiler sebanyak $16,29 \%$ sehingga efisiensi penggunaan ransum dalam menghasilkan produk lebih tinggi.

\section{B. Pengaruh Perlakuan Terhadap Bobot Karkas, Persentase Karkas dan Lemak Abdomen Ayam Broiler.}

Rataan Bobot Karkas, Persentase Karkas dan Persentase Lemak Abdomen Ayam Broiler Masing-masing Perlakuan pada akhir penelitian disajikan pada Tabel 4 .

Pada Tabel 4 dapat dilihat rataan bobot karkas ayam broiler per ekor pada akhir penelitian adalah 1186,71 1520,94 gram. Dari analisis ragam diketahui bahwa pemakaian blondo sampai $12 \%$ (E) dalam ransum memberikan pengaruh yang sangat nyata $(P<0,01)$ terhadap bobot karkas. Setelah uji lanjut diketahui bahwa pemberian blondo sampai level $9 \%$ (D) belum menghasilkan bobot karkas yang berbeda, tetapi pemberian $12 \%$ blondo dalam ransum sangat nyata $(\mathrm{P}<0,01)$ meningkatkan bobot karkas dibandingkan pemberian blondo pada taraf $0 \%(\mathrm{~A}), 3 \%(\mathrm{~B})$, dan $6 \%(\mathrm{C})$.

Semakin tinggi taraf pemberian blondo dalam ransum semakin meningkat pertambahan bobot badan ayam broiler sehingga bobot hidup juga meningkat, dengan meningkatnya bobot hidup menyebabkan bobot karkas juga meningkat. Pada penelitian ini pemberian blondo $12 \%$ dapat meningkatkan bobot karkas sebanyak $28,16 \%$. Ini sesuai dengan pendapat Dwiyanto dkk. (1980) menyatakan bahwa produksi karkas erat hubungannya dengan bobot hidup, dimana semakin bertambah bobot hidup maka produksi karkas semakin meningkat.

Terhadap persentase karkas, hasil analisis ragam menunjukkan bahwa pemakaian blondo sampai level $12 \%$ (E) dalam ransum memberikan pengaruh yang tidak nyata $(P>0,05)$ terhadap persentase karkas ayam broiler, meskipun secara angka persentase karkas meningkat sebanyak $10,35 \%$. Hal ini disebabkan karena persentase karkas merupakan perbandingan antara bobot karkas dengan bobot hidup. Hasil penelitian ini semakin tinggi bobot hidup semakin tinggi juga bobot karkasnya sehingga perbandingan keduanya tidak terdapat perbedaan yang nyata.

Tabel 4. Rataan Bobot Karkas, Persentase Karkas dan Persentase Lemak Abdomen Ayam Broiler Masing-masing Perlakuan.

\begin{tabular}{cccc}
\hline Perlakuan & \multicolumn{3}{c}{ Peubah } \\
\cline { 2 - 4 } & $\begin{array}{c}\text { Bobot karkas } \\
\text { (gram/ekor) }\end{array}$ & Karkas (\%) & $\begin{array}{c}\text { Persentase Lemak } \\
\text { Abdomen (\%) }\end{array}$ \\
\hline A $(0 \%)$ & $1186,71^{\mathrm{A}}$ & 62,23 & 2,41 \\
B $(3 \%)$ & $1261,55^{\mathrm{A}}$ & 63,45 & 2,15 \\
C $(6 \%)$ & $1325,53^{\mathrm{A}}$ & 64,94 & 2,11 \\
D $(9 \%)$ & $1376,08^{\mathrm{AB}}$ & 66,37 & 2,08 \\
E $(12 \%)$ & $1520,94^{\mathrm{B}}$ & 68,67 & 2,07 \\
SE & 44,17 & 2,49 & 0,14 \\
\hline
\end{tabular}

Ket : ${ }^{\text {at }}$ Superskrip berbeda menunjukkan perbedaan yang sangat nyata $(P<0,01)$ 
Hal ini disebabkan karena penyerapan nutrisi dalam ransum meningkat, sehingga bobot badan dan bobot karkas yang didapatkan juga meningkat dengan perlemakan yang sedikit.

Analisis ragam terhadap rataan persentase lemak abdomen memperlihatkan bahwa ransum perlakuan memberikan pengaruh yang tidak nyata $(\mathrm{P}>0,05)$. Dengan demikian meskipun terjadi peningkatan lemak ransum dengan meningkatnya pemberian blondo, ternyata tidak menyebabkan perbedaan lemak abdomen. $\mathrm{Hal}$ ini disebabkan lemak dalam ransum mengandung asam lemak tak jenuh yang dimanfaatkan untuk memenuhi energi untuk kebutuhan hidup pokok dan pertumbuhan bagi ayam.

Meskipun tidak terdapat pengaruh yang nyata namun Tabel 4 memperlihatkan bahwa peningkatan pemberian blondo cendrung menurunkan persentase lemak abdomen. Pemberian blondo $12 \%$ dalam ransum menurunkan persentase lemab abdomen sebanyak $16,43 \%$ Hal ini disebabkan semakin tinggi taraf blondo yang diberikan semakin tinggi asam lemak tak jenuh dalam ransum, yang mana asam lemak tak jenuh ini langsung dibakar oleh tubuh untuk menghasilkan energi tanpa mengalami penumpukan terlebih dahulu. Hal ini sesuai dengan pendapat Sibuea (2004) menyatakan bahwa Asam lemak tak jenuh yang terdapat pada minyak kelapa langsung dibakar oleh tubuh dan menghasilkan energi.

\section{Kesimpulan}

Pemakaian blondo dalam ransum ayam broiler memberikan pengaruh yang baik terhadap performans ayam broiler. Pemberian $12 \%$ blondo meningkatkan pertambahan bobot badan $16,59 \%$, intake lemak ransum $156,68 \%$, bobot karkas 28,16\%, persentase karkas $10,37 \%$, dan menurunkan konversi ransum 16,29 $\%$, dan persentase lemak lemak abdomen $16,43 \%$.

\section{Daftar Pustaka}

Anggorodi, R. 1994. Ilmu Makanan Ternak Umum. Cetakan ke-4 PT. Gramedia, Jakarta. 1995. Nutrisi Aneka Ternak Unggas. PT. Gramedia, Jakarta.

Biro Pusat Statistik Sumatera Barat. 2004. Sumatera Barat dalam Angka. BPS Sumatera Barat, Padang.

Dwiyanto, K., M. Sabrani dan P. Sitorus. 1980. Performans dari Fnam Strain Ayam Pedaging. Buletin Lembaga Penelitian, Bogor. No 25 : 9 17.

NRC. 1984. Nutrient Requirements of Poultry. National Academy of Science, Washington.

North, M. O. 1994. Commercial Chicken Production Manual. $4^{\text {th }}$ ed. The Avi Publishing Company, Connecticutt.

Purwati, E., Husmaini, S. Syukur, dan Y. Murni. 2006. Lactobacillus sp. Isolasi dari Blondo Virgin Coconut Oil Efektif sebagai Probiotik. Proceding Seminar BKS PTS Wil Barat 2006. Universitas Jambi. Jambi.

Mumi, Y. 2006. Kajian potensi Lactobacillus sp dari blondo (waste product virgin coconut oil) sebagai 
probiotik. Skripsi. Jurusan Kimia Fakultas Ilmu Pengetahuan Alam dan Matematika, Padang.

Sarwono, B. 1994. Beternak Ayam Buras. Cet IX. PT. Penebar Swadaya, Jakarta.

Scott, M. L., MC. Nesheim and R. J. Young. 1982. Nutrition of The Chicken. M.L. Scott and Associates, Itacha, New York.

Sibuea, P. 2004. "Virgin Cocomut Oil" Penyembuh Ajaib dan Buah Kelapa. www.kompas.com. Diakses 24 Maret 2005. 09:38:47.

Siregar, A. P. , M. Sabrani dan P. Suroprawiro, 1980. Teknik Beternak Ayam Pedaging di Indonesia. Margie Group, Jakarta.

Alamat Korespondensi : Ir. Husmaini, MP

Jurusan Produksi Ternak Fakultas Peternakan

Universitas Andalas, Kampus Limau Manis, Padang

$\mathrm{HP} ; 08126736590$

Diterima: 12 Januari 2007, Disetujui: 16 Februari 2007
Steel, R. G. D. dan J. H. Torrie, 1995. Prinsip dan Prosedur Statistika: Suatu Pendekatan Biometrik. Alih Bahasa Sumantri, B. PT. Gramedia Pustaka Utama, Jakarta.

Syah, A. N. 2005. "Virgin Coconut Oil" Minyak Kelapa Penakluk Berbagai Aneka Penyakit. PT. Agromedia Pustaka, Bogor.

Syukur, S. 2004. Bioteknologi Virgin Cocomut Oil, Workshop Bioteknologi/ Biomolekuler. Universitas Andalas dan University Putra Malaysia, Padang. 22-25 November.

Wahju, J. 1997. Ilmu Nutrisi Unggas. Gajah Mada University Press, Yokyakarta. 